\title{
The underexploited biotechnology of overexploited Origanum species: Status, knowledge gaps, prospects and potential
}

\author{
Mithilesh Kumar* \& Divya Bhardwaj \\ School of Life Sciences, Jaipur National University, Jaipur 302 017, Rajasthan, India \\ *Email: mithileshkumarbio@gmail.com
}

\section{ARTICLE HISTORY}

Received: 20 May 2020

Accepted: 18 August 2020

Published: 01 October 2020

\section{KEYWORDS}

Oregano

Marjoram

Plant regeneration

Genetic transformation

Anticancer

Therapeutic

Carvacrol

\begin{abstract}
The genus Origanum is a group of phytochemically diverse, aromatic species. Distributed mainly in Eurasia and Mediterranean, they are used in traditional medicine, cosmetics and for culinary purposes. They possess antiproliferative, antioxidant, antiviral, antiseptic, anti-inflammatory, anti-hypertensive properties. The major constituents of Origanum spp. are carvacrol and/or thymol together with $\gamma$ terpinene, $p$-cymene, linalool, terpinene-4-ol and sabinene hydrate. Several flavonoids and glycosides are also found. Although the Origanum spp. can either be cultivated or sourced from nature, high demand has necessitated increased production. Overexploitation from natural habitat has threatened these species. Also, due to its poor viability and small-sized seeds, cross-pollination abilities, less productive vegetative propagation, climate-dependent conventional propagation, its genetic improvement has been limited and thus scientific management of available germplasms through biotechnological approach is necessary. For in-vitro propagation, the literature review showed significant differences in culture protocols, genotypes and their success rates. Studies reported cell culture-based production of secondary metabolites or isolation of active compounds in different species of Origanum, which show antiproliferative activity in cancerous cell lines. However, significant knowledge gaps exist. The urgent need is to use advance technologies in enhancing either plant propagation thus the production of source material for active constituents or for genetic improvement of Origanum germplasms for contents, as well as to validate the therapeutic potential of Origanum constituents. This review critically appraises the status of mostly underexploited biotechnological know-how and research on highly valued medicinal herbs, Origanum and throws light on prospects and potential.
\end{abstract}

\section{Introduction}

The term "traditional medicine" is used interchangeably with complementary or alternative medicine (CAM) which broadly includes herbal medicine and natural medicine (1). Worldwide, 60 $80 \%$ of people depend on traditional herbal medicine for their healthcare, body care and food products, leading to an increased demand for medicinal plant material $(2,3)$. Many of the medicinal plants containing aromatic essential oils are used not only as traditional medicines but also in food, flavour and fragrance industry (2).

The genus Origanum L., belonging to family Lamiaceae, tribe Mentheae comprises of forty-nine taxa including 38 species, 6 subspecies, 3 varieties and remaining hybrids and is characterized by vast taxonomic, morphological, anatomical and chemical diversity. The Origanum species are annual or perennial, shrubby herbs grown and naturally found across many geographical regions. In spite of the multi-purpose medicinal, culinary and cosmetic value of the Origanum species, only less than $50 \%$ species have been subjected to chemical profiling, characterization and biological studies (4).

\section{Distribution}

Origanum populations are primarily distributed in Eurasia and African regions. They have the highest recorded diversity in the Mediterranean, EuroSiberian and Irano-Siberian regions (5). Origanum species are found on stony slopes and in rocky

(c) Kumar \& Bhardwaj (2020). This is an open-access article distributed under the terms of the Creative Commons Attribution License, which permits unrestricted use, distribution and reproduction in any medium, provided the original author and source are credited (https://creativecommons.org/licenses/by/4.0/).

To cite this article: Kumar M, Bhardwaj D. The underexploited biotechnology of overexploited Origanum species: Status, knowledge gaps, prospects and potential. Plant Science Today. 2020;7(4):512-522. https://doi.org/10.14719/pst.2020.7.4.816

Plant Science Today, published by Horizon e-Publishing Group, is covered by Scopus, Web of Science, Clarivate Analytics, BIOSIS Previews, etc. Full list at http://www.plantsciencetoday.online 
mountain areas at a wide range of altitudes $(0-400 \mathrm{~m})$ (6). With reference to biotechnological interventions, two Origanum species are, however, worth special mention. Origanum vulgare L., commonly known as Oregano, wild marjoram, Himalayan marjoram, or as Ban tulsi or Jangli Marwa in India, is widely distributed in Mediterranean areas and Northern Africa and in India, found in the temperate Himalayas from Kashmir to Sikkim at an altitude of 1500-3600 m (4, 5). Origanum majorana L., commonly known as Marjoram, Sweet Marjoram, Knotted Marjoram, Sampsishia or as Marwa in India, is although endemic to Cyprus, cultivated all over Asia, Arabian Peninsula and Africa (4) and is found in Europe as well (7). Both Oregano and Marjoram are one of the most important and largest selling culinary herbs (8).

\section{Uses}

Origanum spp. have been used as herbal medicine, in aromatherapy and as a culinary herb, spice and flavouring agent in food, across many nations and cultures (9). In traditional Indian medicine, medicinal properties of $O$. majorana were known (10). Various medicinal, culinary, cosmetic and other uses (11-34, $45,46)$ of Origanum spp. have been summarized in Fig. 1. Whether used as an essential oil, leaves extract, powder, fresh or dried leaves, marjoram has numerous health benefits $(35,36)$.

\section{Phytoconstituents}

The Origanum biotypes vary in respect of content and/or composition of essential oil in them (36). Essential oil 'rich' species with an essential oil content of $>2 \%$, is mainly characterized either by the dominant presence of carvacrol and/or thymol (together with $\gamma$-terpinene and $p$-cymene) or by linalool, terpinene-4-ol and sabinene hydrate as principal components (37-39). Besides the presence of essential oil, different qualitative phytochemical tests exhibited the presence of flavonoids, tannins, glycosides, cardiac glycosides, sterols, terpenoids in ethanol extract of leaves, root and stem and saponins and carbohydrates in aqueous extracts (40). Considerable amounts of phenolic compounds are generally available in water, methanol, acetone and ethylacetate/water extract of Origanum (11). The phytochemical constituents of $O$. majorana were extensively reviewed (36). Some phenolic glycosides found in marjoram essential oil are Arbutin, Methyl arbutin and Vitexin. Among flavonoids, Hesperetin has been identified in ethyl acetate extract; Catechin, Quercetin, Kaempferol, Naringenine and Eriodictyol in the hydroalcoholic extract and flavonoids like Diosmetin, Luteolin and Apigenin are found in marjoram essential oil (41-43). Rutin, a flavonoid glycoside was identified in marjoram hydroalcoholic extract (44). Besides having Rutin, Quercitin and Eugenol in aerial parts, which give it an advantage as a flavouring agent, $O$. majorana particularly has nutritional benefits as well. Nutritive analysis of dried leaves yields: energy, carbohydrates, fat, dietary fibre; Vitamins- folate, niacin, pantothenic acid, pyridoxine, riboflavin, thiamin, vitamin-A, vitamin-C, vitamin-E, vitamin-K; Electrolytes- sodium, potassium; Minerals- calcium, copper, iron, magnesium, manganese, zinc; and Phytonutrients, $\Omega$ carotene, §-cryptoxanthin, lutein-zeaxanthin (45).

\section{Propagation Means}

Increasing demand for Origanum spp. in the pharma, perfumery and cosmetic industry has necessitated their large scale production. Increases in consumption in recent years may be due in part to the popularity of low-fat, low-salt diets (46). Whether vegetative parts (both green and dry), extracts or essential oil are used $(47,48)$, it necessarily requires better propagation means to make larger quantities of source material available.

Origanum species are either sourced from its natural occurrence in the wild or cultivated. Though they are half-hardy perennial sub-shrubs, they are treated as annual herb under cultivation. In nature, it is found growing on hill-sides and also on limestone and calcareous rocks. When cultivated, propagation is either via seeds or vegetative means (49). Vegetatively, Origanum species can be propagated by cuttings, division or by layering. Under cultivation, they generally require dry, warm, well-drained fertile garden loamy soil and frequent watering. However, it grows well under wide $\mathrm{pH}$ ranges from acidic, neutral to basic soils (7). Marjorams are generally cold-sensitive frost-tender herbs and can be grown outdoors as annuals and replanted in the spring. In plains, seeds are sown in October and in the hills from March to June (50). In contrast, at the higher elevation, sometimes propagation is done by cutting. Seeds can be sown in pots initially and then transplanted in the field. The crop is harvested in 3-4 months. The tops are cut at the time of flowering and dried in the shade. The volatile oil content of the leaves is maximum when the plant is harvested before seed formation. The flowers are hermaphrodite and are pollinated by bees (7).

Though the Origanum sp. can be cultivated and material can be sourced from its natural occurrence also, every cultivation and sourcing method has its problems. For example, propagation via seeds has a considerable disadvantage- as a crosspollinating plant, the offspring of seeds represent populations differing in habit, colour, content and odour of the essential oil (51). Secondly, growing Oregano from seed is not always reliable as seeds have a long dormancy and they germinate poorly if proper temperature and moisture conditions following dormancy are not met (49). In its vegetatively propagated taxa, the poor rooting ability of the stem cuttings and thus non-significant survival efficiency (52) and lack of selected clones, restrain industrial exploitations (53).

On the other hand, sourcing large quantities of the plants material for the preparation, processing and testing of the product and thus overexploitation from natural resources are acting negatively on the populations of the plant and such activities have brought the species at the verge of being endangered. There is a strong need for the application of biotechnological techniques for multiplication and conservation of Origanum species (54) as well as to promote and popularize this wealth among the 


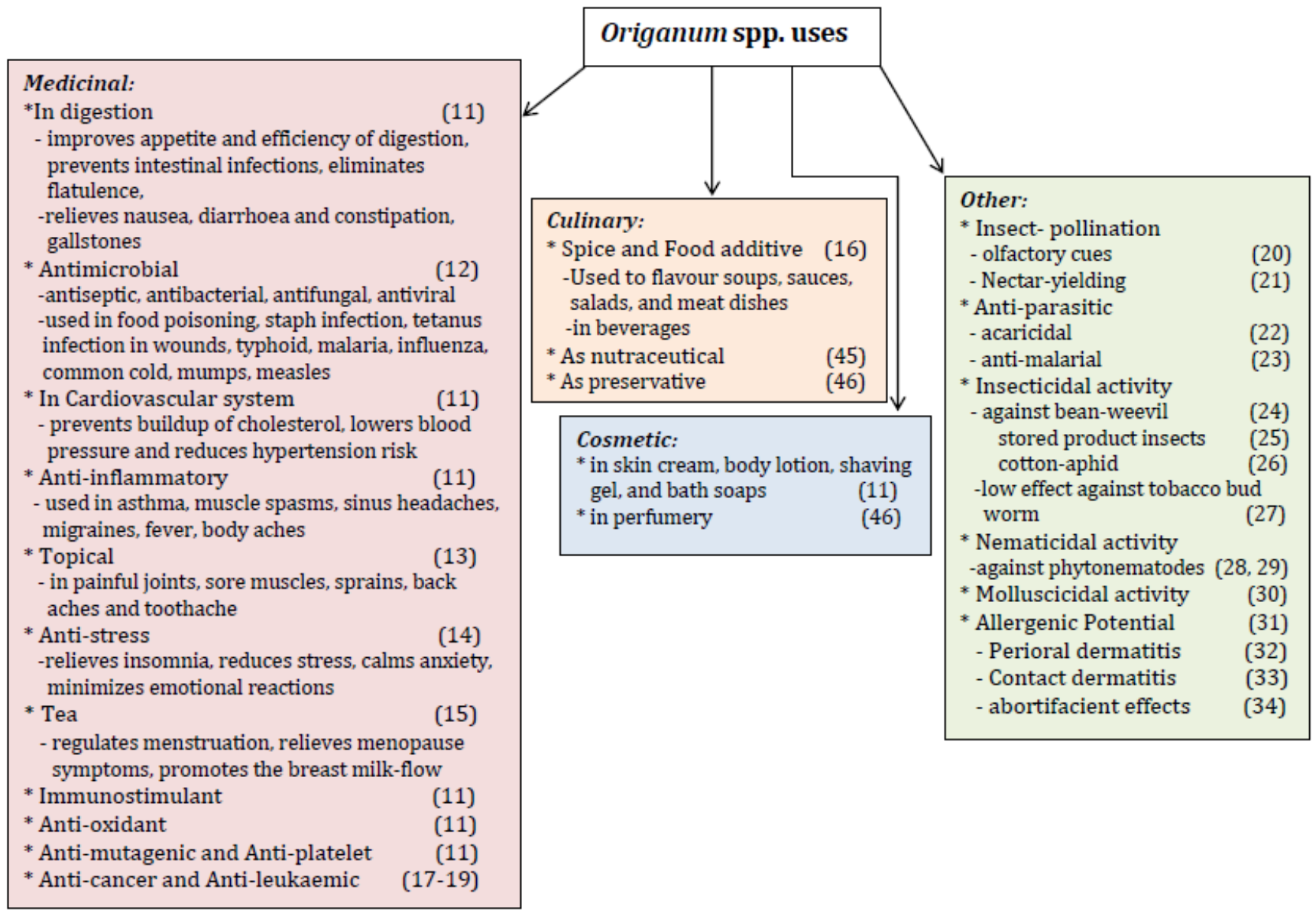

Fig. 1. Various uses of Origanum spp. References are given in parentheses.

farmers, entrepreneurs and pharmaceutical industry (53).

\section{Biotechnological Interventions}

Tissue culture efforts in Origanum vulgare started as early as 1970. A report, while studying the formation of volatile substances in plant tissue cultures, achieved callus induction from stem segments of field-grown $O$. vulgare, on MS media (55) supplemented with different auxins -IAA, NAA or 2,4$\mathrm{D}$ (56). Tissue differentiation leading to regeneration was achieved; however, much later - in O. vulgare (57) and O. majorana (58). The biotechnological efforts put in the species of Origanum has been discussed here under these sections: Plant regeneration in Origanum species; Callus and cell suspension culture for production of secondary metabolites; Genetic transformation; and Antiproliferative properties: effects of extracts/ preparations from Origanum species on cytotoxicity of cancer cells.

\section{Plant Regeneration in Origanum spp.}

In-vitro plant regeneration has been achieved in many species of Origanum. If not all, most of the studies resorted to getting regeneration from preexisting meristems (PEMs) and very few reports claim to have morphogenesis in dedifferentiated cells. A comparative and summarized view of explants, basal culture media and plant growth regulators combination tested for in-vitro regeneration in different species of Origanum reported till date is presented in Table 1.

\section{Plant Materials:}

Explants from various plant parts- either young or mature seedlings or mature plant body, mostly containing PEMs, have been utilized to achieve invitro plant regeneration in many Origanum species (51-54, 57-71, 74).

\section{Surface Sterilization:}

In Origanum tissue culture, wherever seeds or seedlings parts have been used as explants, seeds have been surface-sterilized, subjected to germination and then explants from axenically grown seedlings have been harvested. In $O$. vulgare, $O$. majorana, O. sipyleum $\mathrm{L}$. and $O$. syriacum L., mostly the first step is washing the mature seeds either with $50-70 \%$ ethanol or with $0.01-0.2 \%$ fungicide, followed by treatment with sodium hypochlorite, or mercuric chloride or other disinfectants with varying concentration and time and then washing with sterile water to remove traces of disinfectants $(54,57,58,62,65,70,74)$. The surfacesterilized seeds were germinated on either $0.8 \%$ agar or half or full-strength MS medium with $2 \%$ or $3 \%$ sucrose. In O. minutiflorum Schwarz \& Davis, $O$. acutidens (Hand.-Mazz.)Ietsw. and $O$. onites L., however, seeds were only treated with $5-15 \% \mathrm{NaOCl}$ followed by 3-5 washes with water, before putting them for germination in MS or Gamborg B5 medium in the dark or in the presence of light $(67,68,71)$.

Wherever Origanum explants were taken from mature or naturally grown plants, plant parts were 
Table 1. Studies on In-vitro culture/Plant Regeneration and Callus/ Cell Suspension Culture in Origanum spp.

\begin{tabular}{|c|c|c|c|c|}
\hline \multicolumn{2}{|c|}{ S. No. Explant } & Basal media & PGR combinations & Reference \\
\hline \multicolumn{5}{|c|}{ In-vitro culture / Plant regeneration } \\
\hline \multicolumn{5}{|c|}{ O. majorana } \\
\hline 1 & $\begin{array}{l}\text { Shoot tips and nodal segment from } 30- \\
60 \mathrm{~d} \text { old seedlings }\end{array}$ & MS & 0.5 mg/L Kin. & (58) \\
\hline 2 & Stem nodal Segments & MS & $0.1,10.0 \mathrm{mg} / \mathrm{L}$ BAP; $0.1 \mathrm{mg} / \mathrm{L}$ IBA & (59) \\
\hline 3 & Stem nodal segments and Leaf & $\begin{array}{l}\text { MS with Sucrose/Maltose/ } \\
\text { Glucose }\end{array}$ & 0.1, 0.2 mg/L 2,4-D; 2, 3 mg/L BAP ; 0.2 mg/L IBA & $(60)$ \\
\hline 4 & Axillary buds & MS & 2 mg/L Kin. , 2 mg/L BAP & $(61)$ \\
\hline 5 & Stem nodal segments & MS / P\&C L2 & 9.3 uM Kin. & (52) \\
\hline 6 & Hypocotyl and seed explants & MS & $\begin{array}{l}2 \mathrm{mg} / \mathrm{L} 2,4-\mathrm{D} \text { and } 0.5 \mathrm{mg} / \mathrm{L} \text { Kin. ; } 4 \mathrm{mg} / \mathrm{L} \text { NAA and } \\
0.4 \mathrm{mg} / \mathrm{L} \text { BAP }\end{array}$ & (74) \\
\hline 7 & Cotyledonary node from seedlings & MS & $1 \mathrm{mg} / \mathrm{L}$ BAP & (62) \\
\hline \multicolumn{5}{|c|}{ O. vulgare } \\
\hline 1 & $\begin{array}{l}\text { Cotyledon, hypocotyl and root from } 15 \mathrm{~d} \\
\text { old axenic seedlings }\end{array}$ & B5 & $2,4-\mathrm{D}$ at $10^{-7} \mathrm{M}$; NAA with BAP at $10^{-6} \mathrm{M}$ & (57) \\
\hline 2 & $\begin{array}{l}\text { Shoot tips and nodal segments from } 30- \\
60 \text { d old seedlings }\end{array}$ & MS & $1.0 \mathrm{mg} / \mathrm{L} \mathrm{BAP}$ and $0.5 \mathrm{mg} / \mathrm{L} \mathrm{IBA}$ & (58) \\
\hline 3 & $\begin{array}{l}\text { Young shoot tips from field-grown } \\
\text { plants }\end{array}$ & MS & $0.53 \mathrm{uM}$ NAA and $0.28 \mathrm{uM}$ BAP & (64) \\
\hline 4 & Apical buds from in-vitro grown plants & MS & $8.88 \mathrm{uM}$ BAP and $2.26 \mathrm{uM}$ 2,4-D & (53) \\
\hline 5 & Hairy root segments & MS & $0.25 \mathrm{mg} / \mathrm{L} 2,4-\mathrm{D} ; 0.25 \mathrm{mg} / \mathrm{L}$ BAP & $(65)$ \\
\hline \multicolumn{5}{|c|}{ O. vulgare ssp. hirtum } \\
\hline 1 & Nodal segments & B5 & $0.01 \mathrm{mg} / \mathrm{L} \mathrm{NAA}$ & (63) \\
\hline 2 & Stem tips from $1 \mathrm{wk}$. old seedlings & $\begin{array}{l}\text { Lepoivre nutritional } \\
\text { Environment L4 and L11 }\end{array}$ & $0.15 \mathrm{mg} / \mathrm{L} \mathrm{IAA}$ & (51) \\
\hline \multicolumn{5}{|c|}{ O. sipyleum } \\
\hline 1 & Shoot tips from $17 \mathrm{~d}$ old seedlings & $\begin{array}{l}\text { Modified MS with } 550 \mathrm{mg} / \\
\mathrm{L} \mathrm{CaCl}_{2}\end{array}$ & 1mg/L BAP; 0.5 mg/L BAP & (54) \\
\hline 2 & Nodes from native plants & MS & $0.5 \mathrm{mg} / \mathrm{L} \mathrm{BA} ; 0.2 \mathrm{mg} / \mathrm{L} \mathrm{GA}{ }_{3} ; 1.5 \mathrm{mg} / \mathrm{L} \mathrm{IBA}$ & $(66)$ \\
\hline \multicolumn{5}{|c|}{ O. syriacum } \\
\hline 1 & Stem nodal segments & MS & $2 \mathrm{mg} / \mathrm{L} \mathrm{BAP} ; 0.5 \mathrm{mg} / \mathrm{L} \mathrm{IBA}$ & (69) \\
\hline 2 & $\begin{array}{l}\text { Shoot tips and 1st nodes from } 25 \mathrm{~d} \text { old } \\
\text { seedlings }\end{array}$ & MS & $0.05 \mathrm{mg} / \mathrm{L} \mathrm{NAA}$ and $0.5 \mathrm{mg} / \mathrm{L}$ Kin. ; $1.5 \mathrm{mg} / \mathrm{L} \mathrm{IBA}$ & (70) \\
\hline \multicolumn{5}{|c|}{ O. minutiflorum } \\
\hline 1 & $\begin{array}{l}\text { Nodal segments and shoot tips from } 30- \\
40 \mathrm{~d} \text { old plants }\end{array}$ & MS / B5 & $2 \mathrm{mg} / \mathrm{L} \mathrm{BAP}$ and $0.1 \mathrm{mg} / \mathrm{L} \mathrm{NAA}$ & (67) \\
\hline \multicolumn{5}{|c|}{ O. acutidens } \\
\hline 1 & Node explants from $1 \mathrm{wk}$. old seedlings & MS & $1.8 \mathrm{mg} / \mathrm{L} \mathrm{BAP}$ and $0.2 \mathrm{mg} / \mathrm{L} \mathrm{NAA}$ & (68) \\
\hline \multicolumn{5}{|c|}{ O. onites } \\
\hline 1 & $\begin{array}{l}\text { Hypocotyl, epicotyl, cotyledons, } \\
\text { primary leaves and apical meristem } \\
\text { from } 4 \text { wk. old seedlings }\end{array}$ & MS & 1.5 mg/L Kin. & (71) \\
\hline \multicolumn{5}{|c|}{ O. ehrenbergii } \\
\hline 1 & Stem nodal segments & MS & $2 \mathrm{mg} / \mathrm{L} \mathrm{BAP} ; 0.5 \mathrm{mg} / \mathrm{L} \mathrm{IBA}$ & (69) \\
\hline \multicolumn{5}{|c|}{ Callus and cell suspension culture for production of secondary metabolites } \\
\hline \multicolumn{5}{|c|}{ O. vulgare \& $O$. syriacum } \\
\hline 1 & Leaf & MS & 0.1-0.5 mg/L 2,4-D; 1-1.5 mg/L TDZ & $(72)$ \\
\hline \multicolumn{5}{|c|}{ O. vulgare, $O$. vulgare ssp. hirtum \& $O$. syriacum } \\
\hline 2 & Leaf & MS / LS / B5 & $\begin{array}{l}0.5 \mathrm{mg} / \mathrm{L} 2,4-\mathrm{D} \text { and } 5 \mathrm{mg} / \mathrm{L} \text { Kin. ; } 0.5 \mathrm{mg} / \mathrm{L} \mathrm{NAA} \text { and } \\
3 \mathrm{mg} / \mathrm{L} \text { BAP }\end{array}$ & (73) \\
\hline
\end{tabular}

Abbreviations: d: days; BM: Basal Media; MS: Murashige and Skoog Medium; P\&C L2: Philips and Collins L2 medium; B5: Gamborg-B5 medium; LS: Linsmaier and Skoog medium; N\&N: Nitsch and Nitsch medium; Kin.: Kinetin; BAP: Benzyl Amino Purine; IBA= Indole-3Butyric Acid,; IAA: Indole-3-Acetic Acid; NAA: a-Naphthalene Acetic Acid; 2,4-D: 2,4- dichloro-Phenoxy Acetic Acid; GA 3 : Gibberellic Acid, TDZ: Thidiazuron.

first washed with either a detergent or with $50 \%, 70 \%$ or $95 \%$ ethanol followed by treatment with $1.5-2.0 \%$ or $5-10 \% \mathrm{NaOCl}$ or $5 \% \mathrm{Ca}(\mathrm{ClO})_{2}$ or sometimes with $0.1 \% \mathrm{HgCl}_{2}$ solution for few minutes to disinfect the tissues followed by several washes with water and before preparing the explants for inoculation [O. majorana (59-61); O. vulgare (64, 72); O. sipyleum (66); $O$. syriacum and $O$. ehrenbergii Boiss. (69)]. In one of the reports, however, only a fungicide was used as a surface sterilant after washing with detergent for $O$. majorana stem nodal segments (52).

\section{Basal Media and Media Addenda:}

Tissue culture efforts on Origanum spp. for in-vitro plant regeneration mostly used MS medium as basal medium and supplemented this medium with different plant growth regulators (PGRs) or other addenda. Other media formulations like Gamborg-B5 medium (75), Nitsch and Nitsch medium (76), Phillips 
and Collins (L2) medium (77) were also used to test the explants' response for regeneration.

Various PGRs have been used in tissue culture of species of Origanum. For shoot organogenesis, mostly BAP either alone or in combination with other cytokinins like Kinetin or auxins (IBA, IAA, NAA or 2,4-D) have been tested. However, other cytokinins like 2iP, Zeatin, Adenine sulphate and TDZ have also been used. For rooting, IBA has been the most preferred choice, although other auxins like IAA or NAA have also been used. Interestingly, $\mathrm{GA}_{3}$ was also tested for shoot organogenesis in case of $O$. majorana by one work (52) and in $O$. sipyleum by other (66). Use of other media supplements like amino acids, casein hydrolysate, citric acid, ascorbic acid or activated charcoal was largely not found in the literature for Origanum spp. tissue culture. In our study on $O$. majorana in-vitro regeneration (unpublished data), it was found that the use of activated charcoal reduces polyphenolics and controls browning of the medium, thereby aiding shoot organogenesis. In one work (70), thiamine, glutamine and asparagine were tested as media additive for $O$. syriacum cultures, and it was found that only thiamine supported better shoot organogenesis.

\section{Carbon Source:}

Sucrose has been used as a carbon source by most of the researchers to accomplish plant regeneration in different species of Origanum. While $3 \%$ concentration of sucrose has been shown to be apt by most, $2 \%$ sucrose was used by one (59). Three different carbon sources were tested for O. majorana (60), and it was found that 3\% maltose was best for supporting shoot organogenesis.

\section{Gelling agents:}

In all the reports on tissue culture of various Origanum species, agar has been used invariably as a gelling agent. Whereas a concentration of $0.8 \%$ agar has been most common, some have used different concentrations as well: $0.6 \%$ agar for 0 . minutiflorum (67), $0.62 \%$ agar for 0 . acutidens cultures (68), $0.7 \%$ agar for culturing $O$. syriacum explants (70) and $0.75 \%$ agar for achieving shoot regeneration in $O$. sipyleum (66). Use of Gelrite or Phytagel as a gelling agent was not found in the published reports on Origanum. This is interesting as the production of phenolic acids was demonstrated in $O$. majorana cultures (62). As Gelrite is known for its ability to leach out polyphenolics exuded by plant tissues in culture and thus reducing harmful effects on plant regeneration, it must be tested as a gelling agent for Origanum tissue culture with an imperative to obtain a better morphogenic response.

\section{Culture Conditions:}

Origanum spp. tissue cultures are incubated at a temperature of $25 \pm 2{ }^{\circ} \mathrm{C}$ and a photoperiod of $16 \mathrm{hrs}$, under white fluorescent light in most of the reports. Some have, however utilized a photoperiod of $12 \mathrm{hrs}$ for O. majorana (58-60) and $O$. vulgare $(57,58)$ cultures and one work (74) used a photoperiod of 10 hrs for 0 . majorana cultures. Different temperatures have also been used: $28 \pm 1{ }^{\circ} \mathrm{C}(57), 22{ }^{\circ} \mathrm{C}(64)$ and $26{ }^{\circ} \mathrm{C}$ (65) to $O$. vulgare cultures. A temperature of $26 \pm 2{ }^{\circ} \mathrm{C}$ was used by one study (69) to $O$. syriacum L. and $O$. ehrenbergii Boiss. cultures, while other (51) used a temperature of $28 \pm 1{ }^{\circ} \mathrm{C}$ to $O$. vulgare ssp. hirtum (Link) Ietsw. cultures.

\section{Approaches in In-vitro regeneration of Origanum:}

In almost all in-vitro regeneration reports on any species of Origanum, organogenesis has been the regeneration mode. The shoot organogenesis has been mostly achieved from PEMs- either from shoot apex or from axillary buds. The reports where indirect organogenesis from dedifferentiated cells has been achieved are scanty [in $O$. majorana $(52,60)$; in $O$. vulgare $(57,65)]$. Recently, it was reported that in $O$. onites L., all explants except shoot apical meristem (SAM) developed into non-morphogenic calli and did not show any regeneration (71). Organogenesis is a function of a group of cells having their division products set in fashion to differentiate in a particular organ, which in turn is preceded by meristemoid formation. Meristem organization is, therefore, very tightly regulated in Origanum and it neither disorganizes easily nor reforms (from dedifferentiated cells) easily. Regeneration via somatic embryogenesis is not reported, till date, in any species of Origanum. This also opens up new opportunities for researchers to understand plant regeneration in this important medicinal herb.

Although in-vitro plant regeneration has been demonstrated in many species of Origanum, two types of efforts may be categorized: (a) those where explants are from young seedlings- like cotyledon segments, hypocotyl pieces, cotyledonary node, root segments or shoot tips possessing or devoid of an organized or mature meristem, (b) those where explants are from mature plant parts possessing PEM- like shoot apical meristem, stem node, axillary buds or leaves.

From seedling explants:

In the pioneering study on $O$. vulgare (57), explants were subjected to Gamborg-B5 medium with 2,4-D, NAA and BAP individually and in various combinations of $0,0.1,1$ and $10 \mathrm{uM}$. It was found that whereas callus proliferation was best at $0.1 \mathrm{uM} 2,4-\mathrm{D}$, cotyledon explants was the best source of nodular callus. These calli, when transferred to NAA in combination with $1 \mathrm{uM}$ BAP, developed the highest number of shoots. The best rooting of shoots was achieved on half-strength B5 medium having $1 \%$ sucrose and NAA or IBA at $1 \mathrm{uM}$ concentrations. Shoot apices of $O$. sipyleum were subjected to MS medium with $550 \mathrm{mg} / \mathrm{L} \mathrm{CaCl}$ and $1 \mathrm{mg} / \mathrm{L}$ BAP by one study (54). Multiple shoots were obtained, which were subsequently rooted in MS containing $0.5 \mathrm{mg} / \mathrm{L} \mathrm{IBA.}$ Node explants of $O$. acutidens were cultured on MS medium supplemented with $0.2 \mathrm{mg} / \mathrm{L}$ NAA in combinations with various BAP concentrations (0.6$2.4 \mathrm{mg} / \mathrm{L}$ ) (68). Better shoot organogenesis was observed in this work on a combination of $0.2 \mathrm{mg} / \mathrm{L}$ NAA and $1.8 \mathrm{mg} / \mathrm{L} \mathrm{BAP.} \mathrm{In} \mathrm{another} \mathrm{work} \mathrm{(62),} \mathrm{shoot}$ part including buds from $O$. majorana seedlings were subjected to MS with $3 \%$ sucrose and various concentrations of BAP $(0-1 \mathrm{mg} / \mathrm{L})$. The maximum number of shoots was obtained with $1 \mathrm{mg} / \mathrm{L}$ BAP. They found that in O. majorana, the inclusion of BAP in medium enhanced the number of shoots. In contrast, its omission from medium led to an increase in the length of the regenerated shoots. 
A detailed study of the in-vitro response of $O$. syriacum explants was done (70). Explants were cultured on MS-, Nitsch and Nitsch- and Gamborg-B5media with 3\% sucrose for establishment. After establishment, explants were subjected to MS with 1 $\mathrm{mg} / \mathrm{L}$ of Kinetin, 2iP and BAP and further on various levels $(0-2 \mathrm{mg} / \mathrm{L})$ of Kinetin. It was found that shoot tip was best responsive explant and MS was the best basal medium for culturing $O$. syriacum explants. Strikingly, Kinetin was best-suited cytokinin and shoots cultured on MS with $0.05 \mathrm{mg} / \mathrm{L}$ NAA and 0.5 $\mathrm{mg} / \mathrm{L}$ Kinetin produced the highest amount of shoots. The highest frequency of rooting in regenerated shoots was obtained on MS medium with $1.5 \mathrm{mg} / \mathrm{L}$ IBA. A similar observation was recorded by another study recently (71), which subjected $O$. onites explants to MS medium with varying 0.5-1.5 mg/L Kinetin. They found that SAM explants gave the highest shoot organogenesis in $1.5 \mathrm{mg} / \mathrm{L}$ Kinetin.

From mature plant parts:

Both O. majorana and O. vulgare were studied (58) for in-vitro regeneration response on MS medium with various concentrations of auxins and cytokinins, wherein best shoot organogenesis was reported on $0.5 \mathrm{mg} / \mathrm{L}$ Kinetin in O. majorana explants and on a combination of $1 \mathrm{mg} / \mathrm{L} \mathrm{BAP}$ and $0.5 \mathrm{mg} / \mathrm{L}$ IBA in $O$. vulgare. Stem nodal segments of $O$. majorana were subjected (59) to MS having $2 \%$ sucrose and supplemented with $0.1-10.0 \mathrm{mg} / \mathrm{L}$ BAP for axillary shoot induction. It was found that there is a dosedependent relationship between the number of shoots and BAP concentration, as the maximum number of shoot induction was obtained at $10 \mathrm{mg} / \mathrm{L}$ BAP. However, the length of shoots decreased with increasing the concentration of BAP and maximum shoot length was obtained at $0.1 \mathrm{mg} / \mathrm{L}$ BAP. The regenerated shoots rooted best on MS supplemented with $0.1 \mathrm{mg} / \mathrm{L}$ IBA. Both stem nodal segments and leaf explants from $O$. majorana were, however, tested on MS medium with various concentrations of sucrose, maltose and glucose and with $2 \mathrm{mg} / \mathrm{L}$ BAP for regeneration in another study (60). It was found that the maximum number of regenerated shoots per node was obtained on $3 \%$ maltose with $2 \mathrm{mg} / \mathrm{L}$ BAP. The calli obtained from stem and leaf explants on MS with 3\% maltose augmented with various levels of 2,4-D (0.01-1.0 mg/L) were subjected to MS with BAP, either alone or in combination with IBA, IAA and Kinetin (0.1-10.0 mg/L). Whereas calli obtained from leaf did not regenerate, maximum shoot organogenesis was observed in stem calli on MS with $3 \%$ maltose and a combination of $3 \mathrm{mg} / \mathrm{L} \mathrm{BAP}$ and 0.2 $\mathrm{mg} / \mathrm{L}$ IBA. Highest induction of roots in the regenerated shoots was observed in $0.2 \mathrm{mg} / \mathrm{L}$ IBA. In another study on $O$. majorana (52), stem nodal explants were subjected to MS and Philips and Collins L2 medium supplemented with various concentrations of auxins (IAA, IBA, NAA) or cytokinins (BAP, Kinetin, Adenine sulphate, 2-i-P, TDZ) or $\mathrm{GA}_{3}$ either alone or in combinations (IAA and BAP, IAA and Kinetin and IBA and Kinetin). In general, the P\&C L2 medium was better than MS for shoot organogenesis and both direct and indirect organogenesis was observed. The presence of Adenine Sulphate in medium promoted direct proliferation of shoots from the nodal region, while other cytokinins favoured indirect regeneration of shoots from the callus. The concentrations of $9.3 \mathrm{uM}$ Kinetin (38 shoots) and 13.3uM BAP (33.3 shoots) showed a higher number of shoots from calli. Interestingly, this report demonstrated that even auxins or $\mathrm{GA}_{3}$ alone in the medium could promote shoot organogenesis from nodes, although in low numbers. In $O$. minutiflorum, nodal segments and shoot tips were tested on MS and Gamborg-B5 medium with combinations of BAP $(0,1,2$ or $3 \mathrm{mg} / \mathrm{L})$ and NAA (0, 0.1 or $0.5 \mathrm{mg} / \mathrm{L})$ (67). MS with $2 \mathrm{mg} / \mathrm{L} \mathrm{BAP}$ and $0.1 \mathrm{mg} / \mathrm{L}$ NAA was found best for shoot organogenesis from nodal segments. In a tissue culture report (69) on $O$. syriacum and $O$. ehrenbergii, nodal explants were cultured on MS with 1, 1.5 or 2 $\mathrm{mg} / \mathrm{L} \mathrm{BAP}$ and it was found that $2 \mathrm{mg} / \mathrm{L} \mathrm{BAP}$ was most suitable for shoot multiplication in these two species. Nodes from native plants of $O$. sipyleum were tested on combinations of BAP $(0.1,0.5,1.0 \mathrm{mg} / \mathrm{L})$ and $\mathrm{GA}_{3}$ $(0.1,0.2 \mathrm{mg} / \mathrm{L})$ in MS-based medium and $85 \%$ shoot organogenesis response was obtained on a combination of $0.5 \mathrm{mg} / \mathrm{L} \mathrm{BA}$ and $0.2 \mathrm{mg} / \mathrm{L} \mathrm{GA3} \mathrm{(66).}$ $62.5 \%$ of regenerated shoots rooted in MS medium supplemented with $1.5 \mathrm{mg} / \mathrm{L}$ IBA.

Young shoot tips from field-grown $O$. vulgare $\mathrm{x}$ applii hybrid were cultured on MS with combinations of NAA $(0.53,5.3$, and $5.83 \mathrm{uM})$ and BA $(0.28,2.58$, and $3.86 \mathrm{uM})$ in order to get regeneration response (64). Highest shoot induction was observed by them on NAA (0.53 uM) and BAP (0.28 uM). Shoots with axillary buds of $O$. vulgare ssp. hirtum were subjected to Gamborg-B5 medium with $0.01 \mathrm{mg} / \mathrm{L}$ BAP (63) and shoot, and root induction was obtained on the same medium. Apical buds from in-vitro grown plants of $O$. vulgare were reported to be cultured (53) on MS medium with various concentrations of BAP $(2.22-8.88 \mathrm{uM})$ in combination with either 2,4-D (2.26 - $11.3 \mathrm{uM})$ or NAA (2.68 - $13.42 \mathrm{uM})$ and best shoot induction was observed in MS with 8.88 uM BAP and $2.26 \mathrm{uM}$ 2,4-D. In a report (61) on $O$. majorana, axillary buds were subjected to MS with Kinetin (1 - $3 \mathrm{mg} / \mathrm{L})$ or BAP (1 $3 \mathrm{mg} / \mathrm{L})$. Highest (85\%) shoot organogenesis response was noticed by this report on MS with $2 \mathrm{mg} / \mathrm{L}$ Kin $(30$ shoots), followed by MS with $2 \mathrm{mg} / \mathrm{L}$ BAP $(62 \%$ response, 22 shoots).

All the in-vitro regeneration studies reported so far in any species of Origanum thus point to some of the generalizations: Most of the reports utilized organogenesis as chief mode; Both direct organogenesis from PEMs and indirect organogenesis from dedifferentiated cells are reported, but regeneration from PEMs are more common; direct or indirect somatic embryogenesis has not been achieved for any species of Origanum. Also, protoplast isolation and culture or regeneration from protoplasts for any species of Origanum is not reported. Similar is the case of in-vitro regeneration from inflorescence or any flowering part like sepals or petals. Anther culture, pollen culture, unfertilized ovary culture or production of haploids and regeneration has also not been reported in the published literature.

\section{Vitrification in Origanum tissue culture:}

Vitrification or hyperhydricity is a physiological malformation that is commonly associated with 
tissue culture of many plant species and affects regeneration frequency. Vitrification in tissue culture of $O$. vulgare and strategy to rectify this problem with the help of bacteria isolated from oregano rhizosphere (Pseudomonas spp.) was reported (79). A plant-microbe (O. vulgare -Pseudomonas spp.) interaction that prevents physiological malformations associated with vitrification was suggested (79). Morphological and physiological variations such as water content, chlorophyll content, and total phenolics were compared between vitrified and unvitrified clones. Unvitrified shoots were found to have lower water content and higher chlorophyll and total phenolics compared with vitrified controls. In a further study (80), it was identified that out of several different isolated strains of Pseudomonas spp., mucoidal strains A and F prevented hyperhydricity in O. vulgare cultures in a better way. Shoots inoculated with the non-mucoid strain-NMF showed hyperhydricity and had very similar levels of chlorophyll, solids and phenolics as uninoculated control. Later, hyperhydricity prevention in Oregano by several nonspecific polysaccharides producing rhizosphere bacteria, including Pseudomonas mucidolens and another Pseudomonas sp. was also shown (81). The endophytes and rhizospheric bacteria of $O$. vulgare were shown to possess high anti-oxidant and plant growth-promoting activities and to produce several hydrolytic enzymes (82). However, for commercial micro-propagation of Origanum spp., vitrification in organogenesis-based in-vitro regeneration methods remains a problem. Deploying bacteria to prevent this hyperhydricity is still far from any practical utility.

\section{Callus and cell suspension culture for production of secondary metabolites}

Two studies reported the development of callus and/or cell suspension culture in a few Origanum sp. (Table 1) and compared the presence and amounts of active constituents from their mature plant counterparts $(72,73)$. Leaf explants from 0 . vulgare and $O$. syriacum were cultured on MS medium supplemented with various levels of 2,4-D (0-2 mg/L) to develop callus cultures (72). Callus maintenance was tested on different levels of BAP or TDZ (0.5-2.5 $\mathrm{mg} / \mathrm{L}$ ) with or without $0.5 \mathrm{mg} / \mathrm{L} \mathrm{2,4-D}$. Callus from $3^{\text {rd }}$ generation was used to develop cell- suspension culture in MS liquid medium with $1 \mathrm{mg} / \mathrm{L}$ TDZ. Whereas better callus production and their fresh weight were observed on the lower range of 2,4-D (0.1-0.5 mg/L), best callus maintenance was observed on 1-1.5 $\mathrm{mg} / \mathrm{L}$ TDZ without 2,4-D. Gas chromatography (GC) was performed and oil content and thymol contents were analyzed in greenhouse and in-vitro grown plants and calli and cell suspension culture extracts. In-vitro grown plants of $O$. vulgare had the highest oil content in comparison to its callus and cell culture, but no thymol was present. In $O$. syriacum, greenhouse-grown plants showed highest thymol percentage, and thymol was not detected in calli or cell suspension culture.

Another report (73), also utilized leaf explants from $O$. vulgare, $O$. vulgare var. hirtum and $O$. syriacum to develop callus cultures and compared the extracts of farm-grown plants and callus. Explants were subjected to MS, LS or B5 media along with various concentrations and combinations of 2,4-D, Kinetin, NAA and BAP. Out of the three media they tested for callus production and growth, MS was the best. A combination of $0.5 \mathrm{mg} / \mathrm{L} 2,4-\mathrm{D}-5 \mathrm{mg} / \mathrm{L}$ Kinetin and $0.5 \mathrm{mg} / \mathrm{L}$ NAA- $3 \mathrm{mg} / \mathrm{L}$ BAP in MS produced highest amount of callus. GC and GC -MS of extracts showed the presence of 21 compounds in $O$. vulgare calli, 24 compounds in O. vulgare var. hirtum and 26 compounds in $O$. syriacum calli. Carvacrol and apinene were detected in all three species. Thymol was detected only in $O$. vulgare. Carene- $\delta-2$ was found only in $O$. syriacum and $O$. vulgare. The results obtained by later study (73) were, however, in contrast with earlier (72), who has not detected any thymol in $O$. vulgare.

Above two studies provided the basis that Origanum callus or cell-suspension culture may be utilized for obtaining active constituents. Nevertheless, significant scope exists in establishing the Origanum cell culture for enhanced production of the desired metabolite in a controlled environment. The clones with higher content(s) and genetic engineering for improved accumulation will be relevant to the needs of pharmaceutical industries. Moreover, it will reduce the overexploitation of Origanum spp. from nature for sourcing the plant material.

\section{Genetic transformation of Origanum spp.}

Since the advent of genetic engineering of plants for incorporating useful traits not available in their germplasms or from any of their wild relatives, a large number of plant species have been genetically transformed with many genes to bring in those useful traits in the transgenic plant lines, utilizing different direct or indirect genetic transformation methods. In spite of the much-acclaimed value of Origanum medicinal herbs, unfortunately, no report exists that detail the standardization of genetic transformation in any Origanum spp.; nor the development of a transgenic plant with a useful gene is reported in the published literature. Although a study (65) reported genetic transformation of $O$. vulgare with Agrobacterium rhizogenes and regeneration from hairy root-derived callus, their purpose was neither development of transgenic Oregano nor enhancing/tapping the secondary metabolite content in $O$. vulgare hairy roots. The leaf explants from 20-25 days old oregano plants were infected with two strains of $A$. rhizogenes. Bacterial cells were harvested at $\mathrm{OD}_{600} \mathrm{~nm}$ of 0.8 , and the infection medium contained MS salts with $50 \mathrm{mg} / \mathrm{L}$ sucrose. Six co-cultivation media were tested, each containing MS medium with $100 \mathrm{uM}$ acetosyringone but lacking one or more major or minor salt. After co-cultivation for two days, explants were cultured in hormone-free MS medium with $3 \%$ sucrose and $200 \mathrm{mg} / \mathrm{L}$ cefotaxime. Both strains were found effective in inducing hairy roots in oregano explants after two weeks. Highest induction $(91.3 \%)$ was noted on co-cultivation medium-5 (lacking $\mathrm{KH}_{2} \mathrm{PO}_{4}, \mathrm{NH}_{4} \mathrm{NO}_{3}, \mathrm{KNO}_{3}$ and $\mathrm{CaCl}_{2}$ ).

For transgenic plant development, usually, a high-frequency genetic transformation protocol is coupled to a reproducible in-vitro plant regeneration system. Preferably, compatible A. tumefaciens strainbinary vector system harbouring gene of interest is required. Infected explants are cultured on selection 
medium to select transformed cells which can eventually be subjected to regenerate into complete plant body. Most of the regeneration protocol in Origanum species reported so far utilizes organogenesis from pre-existing meristems, and generally, meristem based regeneration of transformed cells lead to transgenic plants with the chimeric organization. Thus it is necessary to develop a compatible transformation-regeneration system in Origanum spp. for homogeneous, stable and faithful expression of the transgene in all the cells of transformed regenerants. Further, the optimizations of various factors affecting $A$. tumefaciens -mediated transformation are needed.

\section{Antiproliferative properties: Effects of extracts/ preparations from Origanum spp. on cytotoxicity of cancer cells}

Scientific investigation into anticancerous properties of Origanum phytoconstituents started with a study in 1987 (17), where hydroquinone isolated from $O$. majorana was demonstrated to have potent cytotoxicity on cultured rat hepatoma cells (HTC). Whereas this initial study indicated that marjoram constituents have antiproliferative potential, a detailed study and action mechanisms of these phytoconstituents were presented by a 2010 report (83). The antiproliferative activity of ethanolic extracts from marjoram leaves was tested on human lymphoblastic leukaemia cell line-Jurkat. At noncytotoxic concentrations, the viability of cells decreased with the increase of plant extract concentration. The antiproliferative effect was also found to be dose-dependent. Marjoram extracts were shown to stimulate apoptosis, which in turn was induced by an up-regulation of p53 protein levels and down-regulation of Bcl-2a. The conclusions from this study suggested that phenolic content-rich marjoram extracts exhibit strong antioxidant and scavenging activities and high antiproliferative effect.

$O$. majorana and $O$. vulgare essential oils and their constituents were compared for cytotoxicity against different cancer cell lines (84). In the MTT assay, O. majorana essential oil (OmEO) was more cytotoxic than $O$. vulgare essential oil (OvEO) against different cancer cell types, such as MCF-7, LNCaP and NIH-3T3. Another study (85) reported the cytotoxic activity of ethyl acetate and ethanol extracts from leaves of $O$. compactum in human breast cancer cell line - MCF7.

The anti-metastatic and anti-tumour growth effects of marjoram ethanolic extracts on highly metastatic human breast cancer cell line- MDA-MB231 was also presented (86), where it was shown that O. majorana promotes inhibition of tumour growth and metastasis in-vivo. Ethanol extract from $O$. majorana (87) was found to show significant cytotoxicity $(\mathrm{P}<0.001)$ to fibrosarcoma and least toxicity to normal human lymphocytes when compared to the controls. Ethanolic extract of $O$. syriacum was shown to inhibit human leukaemia THP-1 cells (18). In this work, ethanolic extracts from aerial parts of $O$. syriacum and Thymus vulgaris L. were investigated against the THP-1 leukaemia cell line and freshly isolated peripheral blood mononuclear cells (PBMCs). Both extracts exhibited a concentration-dependent reduction in viability of the
THP-1 cells. However, O. syriacum was more potent against the PBMCs, while T. vulgaris was moderately selective. In $O$. syriacum the reduction in cells viability was caused by cytotoxic effect against leukemic cells of THP-1.

A study (88) identified 71 compounds in the essential oil obtained by hydrodistillation of aerial parts of $O$. vulgare and tested both crude essential oil (EO) extract as well as single substances for cytotoxicity to carcinoma and non-tumour cell line. The crude EO extract has significantly reduced the cell viability of the hepatocarcinoma cell line (HepG2) in dose-dependent mode, as compared to the vehicle control. Interestingly, results showed that oregano EO has lower cytotoxic activity against non-tumour cell line HEK293. While testing of single substances for cytotoxicity against HepG2 cells, they noted that carvacrol and citral showed the highest significant reduction of cell viability of hepatocarcinoma cells. Thymol and limonene showed a viability reduction of HepG2 cells.

Aqueous, petroleum ether, dichloromethane, ethylacetate and methanol extracts were prepared from aerial parts of marjoram, and these extracts were tested (89) for cytotoxicity against breast cell line (MDA-MB231) and colon cancer cell line (HT-29 cells). All extracts of $O$. majorana tested against both types of cancer cells showed a more pronounced cytotoxic effect against MDA-MB-231 than HT-29 cells. In-vitro cytotoxic tests showed that extracts inhibit the proliferation of human cancer cell lines in a dose-dependent manner. Recently, the essential oil obtained from hydrodistillation of aerial parts of $O$. onites (OoEO) was examined for its antiproliferative activity against melanoma cells (A375), breast cancer cells (MCF-7), hepatocellular carcinoma cells (HepG2) and colon cancer cells (HT-29) (90) Interestingly, OoEO exhibited a dose-dependent antiproliferative activity against all human cancer cell lines tested. The most potent antiproliferative effect was observed in the HT-29 colon cancer cell line followed by A375 skin melanoma, MCF-7 breast carcinoma, and HepG2 hepatocellular carcinoma cells. OoEO attenuated migration and induced apoptosis-related morphological changes in both human (HT-29) and murine (CT26) colon cancer cell lines. The anticancerous activity of ethanolic extracts prepared from dried marjoram leaves was also recently studied on two human colon cancer lines (HT-29 and Caco-2) and the findings provide strong evidence that $O$. majorana extract (OmE) possesses strong anti-colon cancer potential, at least, through induction of autophagy and apoptosis (19). They showed that OmE exhibited this antiproliferative activity in a concentration- and time-dependent manner. OmE inhibited cell viability, colony growth and induced mitotic arrest of HT-29 cells. Also, OmE induced DNA damage, triggered abortive autophagy and activated a caspase 3 and 7-dependent extrinsic apoptotic pathway, most likely through the activation of the TNF-a pathway. The time-course analysis revealed that DNA damage occurred concomitantly with abortive autophagy 4 hours post-OmE treatment, while apoptosis was activated only $24 \mathrm{hrs}$ later. Blockade of autophagy initiation (by 3-methyladenine) partially rescued OmEinduced cell death.

All the works mentioned above in this section lead to some generalizations: (i) Antiproliferative 
activity of Origanum is concentration-dependent (in the range which is non-cytotoxic to normal cells), (ii) Although Origanum phytoconstituents have strong antioxidant and radical scavenging activity, the antiproliferative activity was shown to be mediated through induction of autophagy and apoptosis. (iii) Many different cancer cell lines -HTC, HepG2, Jurkat, THP-1, MCF-7, MDA-MB-231, HT-29, Caco-2, A375, LNCaP and NIH-3T3 have been tested to demonstrate the anticancerous properties of phytoconstituents of Origanum species, but still far from real practical use, (iv) Mostly, crude extracts have been tested, but a few have shown the efficacy of isolated constituents like Carvacrol, Citral and Hydroquinone for cytotoxicity of cancerous cells and (v) $O$. marjoram phytoconstituents have been mostly used to demonstrate this cancer cells cytotoxicity, followed by $O$. vulgare; however, phytoconstituents of $O$. syriacum, $O$. onites and $O$. compactum have also been reported.

\section{Conclusion}

Scientific investigations into medicinal plants nowadays are emphasizing on selecting and identifying useful compounds, validating their individual or in combination efficacy as well as to increase the production and availability of source material or plants. Origanum, with its many species and multi-purpose medicinal value, has been found to be an excellent source of such compounds. The present review point to the fact that significant opportunities exist for research in exploring and placing the therapeutic potential of isolated phytoconstituents, their consortia or crude extracts of Origanum species in designing the anticancer medicines. This also puts forward a fiery need to enhance the propagation of Origanum species across continents. However, the literature survey reveals the research gaps in standardized, highfrequency in-vitro regeneration and genetic transformation protocols of different species of Origanum. It will be prudent to develop somatic embryogenesis based mass propagation methods and high-frequency $A$. tumefaciens- mediated transformation protocols for Origanum spp. Model genotypes could be identified which respond to a wider range of regeneration protocols, or regeneration protocol could be developed which perform relatively better over a wider range of Origanum genotypes. The lines with higher contents of desired constituents, if subjected to mass propagation, will boost industries interested in Origanum compounds. Origanum cell culture systems need to be developed, and metabolic engineering should be attempted to enhance the bioactive secondary metabolites. In this context, biotechnological efforts on these species are overly underexploited, keeping in view 'since time immemorial' exploitation of this culinarily and medicinally valuable plant species.

\section{Acknowledgements}

Authors are grateful to the School of Life Sciences, Jaipur National University, Jaipur, India for providing necessary infrastructure and support for this work.
Authors' contributions

All authors contributed equally.

\section{Conflict of interests}

Authors declare no conflict of interest.

\section{References}

1. Davuluri S, Dharmarajan TS. Complementary and alternative medicine- herbals and supplements: a review for the primary care physician. Cureus. 2014; 6(6):e184. https://doi.org/10.7759/ cureus.184

2. Balick MJ. Transforming ethnobotany for the new millennium. Ann Missouri Bot Gard. 1996; 83(1): 58-66. https://doi.org/10.2307/2399968

3. Voeks RA, Leony A. Forgetting the forest: assessing medicinal plant erosion in Eastern Brazil. Econ Bot. 2004;58 (s): S294-06. https://doi.org/10.1663/00130001(2004)58[S294:FTFA MP]2.0.CO;2

4. Chishti S, Kaloo ZA, Sultan P. Medicinal importance of genus Origanum: A review. J Pharmacognosy Phytother. 2013;5(10):170-77. https://doi.org/10.5897/JPP2013.0285

5. Ietswaart JH. A taxonomic revision of the genus Origanum (Labiatae). Leiden Botanical series. Leiden: Leiden University Press; 1980:1-160. https://doi.org/10.1007/978-94-009-9156-9_1

6. Snogerup S. Evolutionary and plant geographical aspects of Chasmophytic communities. In: Davis PH, Harper PC, Hedge IC, (editors). Plant Life of South-West Asia. Edinburgh: The Botanical Society; 1971:157-70.

7. Prerna, Vasudeva N. Origanum majorana L. -Phytopharmacological review. Indian J Nat Prod Resour. 2015;6(4):261-67.

8. Kintzios SE. Profile of the multifaceted prince of the herbs. In: Kintzios SE, (editor). Oregano: the genera Origanum and Lippia. London : Taylor \& Francis; 2002:236-42.

9. Fleisher A, Fleisher Z. Identification of Biblical Hyssop and origin of the traditional use of oregano-group herbs in the mediterranean region. Econ Bot. 1988;42(2): 232-41. https://doi.org/10.1007 /BF02858924

10. Sharma PV. Indian medicine in the classical age. Varanasi: Chaukhamba Amarabharati Prakashan; 2000:134-212.

11. Tripathy B, Satyanarayana S, Abedulla Khan K, Raja K. An updated review on traditional uses, taxonomy, phytochemistry, pharmacology and toxicology of Origanum majorana. Int J Pharma Res Health Sci. 2017;5:1717-23. https:// doi.org/10.21276/ijprhs.2017.04.01

12. Kordali S, Cakir A, Ozer H, Cakmakci R, Kesdek M, Mete E. Antifungal phytotoxic and insecticidal properties of essential oil isolated from Turkish Origanum occidentis and its three components, carvacrol, cymol, p-cymene. Bioresour Technol. 2008;99(18): 8788-95. https://doi.org/10.1016/ j.biortech.2008.04.048

13. Dudus LE, Bodrug MV, Nemtsanu NN, Kokosh EN, Shashlik sauce. USSR Patent No. 906497, 1982.

14. Busatta C, Vidal RS, Popiolski AS, Mossi AJ, Dariva C, Rodrigues MR, Corazza FC, Corazza ML, Vladimir Oliveira J, Cansian RL. Application of Origanum majorana L. essential oil as an antimicrobial agent in sausage. Food Microbiol. 2008;25:20711. https://doi.org/10.1016/j.fm.2007.07.003

15. Faleiro L, Miguel G, Gomes S, Costa L, Venâncio F, Teixeira A, Figueiredo AC, Barroso JG, Pedro LG. Antibacterial and antioxidant activities of essential oils isolated from Thymbra capitata (L.) Cav. and Origanum vulgare L. J Agric Food Chem. 2005;53(21): 8162-68. https://doi.org/10.1021/jf0510079

16. Farrell KT. Spices, condiments, and seasonings. westport: AVI Publishing Company Inc.; 1985:6:415. https://doi.org/10.1002/food.19860301083

17. Assaf MH, Ali AA, Makboul MA, Beck JP, Anton R. Preliminary study of phenolic glycosides from Origanum majorana, quantitative estimation of arbutin, cytotoxic activity of hydroquinone. Planta Med. 1987;53(4):343-45. https://doi.org/10.1055/s-2006-962734

18. Ayesh BM, Abed AA, Faris DM. In- vitro inhibition of human leukemia THP-1 cells by Origanum syriacum L. and Thymus vulgaris L. extracts. BMC Res Notes. 2014;7:612. https://doi.org/ 10.1186/1756-0500-7-612 
19. Benhalilou N, Alsamri H, Alneyadi A, Athamneh K, Alrashedi A, Altamimi N, Al Dhaheri Y, Eid AH, Iratni R. Origanum majorana ethanolic extract promotes colorectal cancer cell death by triggering abortive autophagy and activation of the extrinsic apoptotic pathway. Front Oncol. 2019; 9:795. https://doi.org/10.3389/fonc.2019.00795

20. Beker R, Dafni A, Eisikowitch D, Ravid U. Volatiles of two chemotypes of Majorana syriaca L. (Labiatae) as olfactory cues for the honeybee. Oecologia. 1989;79(4):446-51. https://doi.org/10.1007/BF00378659

21. Jablonski B. Nectar secretion and honey productivity of important honey plants in polish conditions. Pszczelnicze Zeszyty Naukowe. 1986;30:195-05.

22. Long LT, Koeniger N, Fuchs S. Varroa treatment with combination of formic acid and oil of marjoram: laboratory tests and field experiments. Apidologie. 1997;28(3-4):179-81.

23. Milhau G, Valentin A, Benoit F, Mallie M, Bastide JM, Pelissier Y, Bessiere JM. In-vitro antimalarial activity of eight essential oils. J Essent Oil Res. 1997;9(3):329-33. https://doi.org/10.1080/10412905.1997.10554252

24. Baricevic D, Milevoj L, Borstnik J. Insecticidal effect of oregano (Origanum vulgare L. ssp. hirtum Ietswaart) on the dry bean weevil (Acanthos celidesobtectus Say). Int J Hortic Sci. 2001; 7(2): 84-88. https://doi.org/10.31421/IJHS/7/2/272

25. Shaaya E, Kostjukovski M, Eilberg J, Sukprakarn C. Plant oils as fumigants and contact insecticides for the control of storedproduct insects. J Stored Prod Res. 1997; 33(1):7-15. https://doi.org/10.1016/S0022-474X(96)00032-X

26. Tunc I, Sahinkaya S. Sensitivity of two greenhouse pests to vapours of essential oils. Entomol Exp et Appl. 1998;86(2):18387. https://doi.org/10.1046/j.1570-7458.1998.00279.x

27. Isman $\mathrm{MB}$, Wan $\mathrm{AJ}$, Passreiter CM. Insecticidal activity of essential oils to the tobacco cutworm, Spodoptera litura. Fitoterapia. 2001;72:65-68. https://doi.org/10.1016/s0367326x(00)00253-7

28. Abd-Elgawad MM, Omer EA. Effect of essential oils of some medicinal plants on phytonematodes. Anz Schadlingsk, Pflanzenschutz, Umweltschutz. 1995;68(4):82-84. https://doi.org/10.1007/BF01908429

29. Oka Y, Nacar S, Putievsky E, Ravid U, Yaniv Z, Spiegel Y. Nematicidal activity of essential oils and their components against the root-knot nematode. Phytopathology. 2000;90(7):710-15. https://doi.org/10.1094/PHYTO.2000.90.7.710

30. Hmamouchi M, Lahlou M, Agoumi A. Molluscicidal activity of some Moroccan medicinal plants. Fitoterapia. 2000;71(3): 30814. https://doi.org/10.1016/S0367-326X(99)00152-5

31. Benito M, Jorro G, Morales C, Pelaez A, Fernandez A. Labiatae allergy: systemic reactions due to ingestion of oregano and thyme. Ann Allergy Asthma Immunol. 1996;76(5):416-18. https://doi.org/10.1016/S1081-1206(10)63456-4

32. Farkas J. Perioral dermatitis from marjoram, bay leaf and cinnamon dermatitis from marjo 1981;7(2):121 https://doi.org/10.1111/j.1600-0536.1981.tb03993.x

33. Futrell JM, Rietschel RL. Spice allergy evaluated by results of patch tests. Cutis. 1993;52(5):288-90. PMID: 8299390.

34. Brinker F. Herb Contraindications and Drug Interactions. Oregon: Eclectic Medical Publications; 1998;263.

35. Baricevic D, Bartol T. The biological/pharmacological activity of the Origanum genus. In: Kintzios S (editor). Medicinal and Aromatic Plants-Industrial Profiles. London: Taylor \& Francis; 2002;177-14.

36. Bina F, Rahimi R. Sweet marjoram: a review of ethnopharmacology, phytochemistry and biological activities. J Evid Based Complementary Altern Med. 2017;22:175-85. https://doi.org/10.1177/ 2156587216650793

37. Akgul A, Bayrak A. Constituents of essential oils from Origanum species growing wild in Turkey. Planta Med. 1987;53(1):114. https://doi.org/10.1055/s-2006-962644

38. Tumen G, Baser KHC. The essential oil of Origanum syriacum L. var. bevanii (Holmes) Ietswaart. J Essent Oil Res. 1993;5:315-16. https://doi.org/10.1080/10412905.1993.9698227

39. Kokkini S. Taxonomy, diversity and distribution of Origanum species. In: Proceedings of the IPGRI International Workshop on Oregano; 1996 May 8-12; Italy. Bari:CIHEAM; 1997. p.2-12.

40. Singla P, Vasudeva N. Pharmacognostical and quality control parameters of Origanum majorana Linn. Stem and root, World J Pharm Pharmaceut Sci. 2014;3(6):1428-37.
41. Mossa AT, Refaie AA, Ramadan A, Bouajila J. Amelioration of prallethrin-induced oxidative stress and hepatotoxicity in rat by the administration of Origanum majorana essential oil. Biomed Res Int. 2013; 2013:859085. https://doi.org/10.1155/2013/859085

42. Vallverdu-Queralt A, Regueiro J, Rinaldi Alvarenga JF, Martinez-Huelamo M, Leal LN, Lamuela-Raventos RM. Characterization of the phenolic and anti- oxidant profiles of selected culinary herbs and spices: caraway, turmeric, dill, marjoram and nutmeg. Food Sci Technol (Campinas). 2015;35(1):189-95. https://doi.org/10.1590/1678-457X.6580

43. Erenler R, Sen O, Aksit H, Demirtas I, Yaglioglu AS, Elmastas $\mathrm{M}$, Telci I. Isolation and identification of chemical constituents from Origanum majorana and investigation of antiproliferative and antioxidant activities. J Sci Food Agric. 2016;96:822-36. https://doi.org/10.1002/jsfa.7155

44. El-Moursi A, Talaat IM, Balbaa LK. Physiological effect of some antioxidant polyphenols on sweet marjoram (Majorana hortensis) plants. Nusantara Biosci. 2012;4:11-15. https://doi.org/10.13057/ nusbiosci/n040103

45. Srinivasan K. Role of spices beyond food flavoring Nutraceuticals with multiple health effects; Food Reviews International, 2005;21:167-88. https://doi.org/10.1081/FRI200051872

46. Oliver GW. The world market of oregano. In: Proceedings of the IPGRI International Workshop on Oregano;1996 May 8-12; Italy. Bari: CIHEAM; 1997. p.141-45.

47. Cetin B, Cakmaci S, and Cakmakci R. The investigation of antimicrobial activity of thyme and oregano essential oils. Turkish Journal of Agriculture and Forestry. 2011;35(2):145-54 https://doi.org/10.3906/tar-0906-162

48. Ozkan G, Sagdıc O, Ekıcı l, Ozturk I, Ozcan MM. Phenolıc compounds of Origanum sipyleum L. extract and its antioxidant and antibacterial activities. J Food Lipids. 2007;141(2):157-69. https://doi.org/10.1111/j.1745-4522.2007.00077.x

49. Farashah HD, Afshari RT, Sharifzadeh F, Chavoshinasab S Germination improvement and $\alpha$-amylase and $\beta$-1,3-glucanase activity in dormant and non-dormant seeds of Oregano (Origanum vulgare). Aust J Crop Sci. 2011;5(4):421-27.

50. Anonymous. Origanum majorana, The Wealth of India-A Dictionary of Indian Raw Material, New Delhi, Council of Scientific and Industrial Research. 1992;98:226-27.

51. Nanova Zh, Slavova Y. Mass Vegetative Propagation of Winter Marjoram (Origanum vulgare ssp. hirtum (Link) Ietswaart. Bulg J Agric Sci. 2006;12:531-36.

52. Tejvathi DH, Padma AV. In-vitro multiplication of Majorana hortensis Moench- An aromatic medicinal herb. Indian J Plant Sci. 2012;1(1):48-56.

53. Leelavathi D, Kuppan N. Callus induction and regeneration of multiple shoots from in-vitro apical bud explant of Origanum vulgare, An important medicinal plant. Int J Res Pharm Chem. 2013;3(4):898-03.

54. Oluk EA, Çakır A. Micropropagation of Origanum sipyleum L., an endemic medicinal herb of Turkey. African J Biotechnol. 2009; 8(21): 5769-72. https://doi.org/10.5897/AJB09.1216

55. Murashige T, Skoog F. A revised medium for rapid growth and bioassays with tobacco tissue cultures. Physiol Plant. 1962;15:473-97. https://doi.org/10.1111/j.13993054.1962.tb08052.x

56. Becker H. Studies on the formation of volatile substances in plant tissue cultures. Biochem. Physiol Pflanzen. 1970;161:42541. https://doi.org/10.1016/S0015-3796(17)31070-3

57. Kumari N, Saradhi PP. Regeneration of plants from callus cultures of Origanum vulgare L. Plant Cell Rep. 1992; 11 (9): 476-79. https://doi.org/10.1007/BF00232694

58. Sajina A, Geetha SP, Minoo D, Rema J, Nirmalbabu K, Sadanandan AK, Ravindran PN. Micropropagation of some important herbal species. In: Proceedings of Biotechnology of Spices, Medicinal and Aromatic Plants; 1996 Apr 24-25; India. Calicut: Indian Society for Spices; 1997. p. 79-86.

59. Iyer PV, Pai JS. Micropropagation of sweet marjoram (Majorana hortensis Moench). J Spices Aromat Crops. 1998;7(1):47-49.

60. Iyer PV, Pai JS. In vitro regeneration of Majorana hortensis Moench from callus and nodal segments. J Spices Aromat Crops. 2000;9 (1):47-50. 
61. Yashodabai S, Gayatri MC, Leelavathi D. In-vitro propagation of Oreganum majorana using axillary bud explants. J Cytol Genet. 2011;12:71-75.

62. Korkor AM, Mohamed SA, Abd Al-Kafie OM, Gohar AA. Adaptation of the in-vitro culture of Origanum majorana L. for production of phenolic acids. Journal of Pharmacy and Biological Sciences. 2017;12(2):30-38 https://doi.org/10.9790/3008-1202013038

63. Iconomou-Petrovich GN, Nianiou-Obeidat I. Micropropagation of Origanum vulgare subsp. hirtum (Mt. Taygetos). In: Tsekos I Moustakas M, (editors). Progress in Botanical Research; 1998; Germany. Berlin: Springer; 1998. p. 509-12. https://doi.org/10.1007/978-94-011-5274-7_116

64. Goleniowski ME, Falmarique C, Bima P. Micropropagation of Oregano (Origanum vulgare $\mathrm{x}$ applii) from meristem tips. In vitro Cell Dev Biol- Plant. 2003;39:125-28. https://doi.org/10.1079/ IVP2002361

65. Habibi P, Grossi de Sa MF, Lopes da Silva AL, Makhzoum A, da Luz Costa J, Borghetti IA, Soccol CR. Efficient genetic transformation and regeneration system from hairy root of Origanum vulgare. Physiol Mol Biol Plants. 2016;22(2):271-77. https://doi.org/10.1007/s12298-016-0354-2

66. Sevindik B, Izgu T, Simsek O, Tutunku M, Curuk P, Yilmaz O, Kaynak, G, Aka Cakar Y, Teixeira da Silva JA and Mendi YY. Invitro Culture of Turkish Origanum sipyleum L. American Journal of Plant Biology. 2017; 2(5-1):32-36. https://doi.org/10.11648/j.ajpb.s.2017020501.16

67. Ozkum D. In-vitro shoot regeneration of Oregano (Origanum minutiflorum O. Schwarz \& Davis). Hacettepe J Biol Chem. 2007;35(2):97-100.

68. Yildirim MU. Micropropagation of Origanum acutidens (Hand.Mazz.) Ietswaart using stem node explants. Sci World J. 2013:13. https://doi.org/10.1155/2013/276464

69. El Beyrouthy M, Elian G, AbouJaoudeh C, Chalak, L. In-vitro propagation of Origanum syriacum and Origanum ehrenbergii. Acta Hortic. 2015;1083:169-72. https://doi.org/10.17660/ActaHortic.2015.1083.19

70. Abdallah SAS, Yakoup MYA and Abdalla MYH. Micropropagation of Oregano (Origanum syriacum L.) through tissue culture technique. J Plant Prod, Mansoura Univ. 2017; 8 (5): 635 -39. https://doi.org/10.21608/jpp.2017.40497

71. Avtar H, Colgecen H. Regeneration in Origanum onites L. by Plant Tissue Culture. Karaelmas Sci Eng J 2019;9(2):177-80. http://dx.doi.org/10.7212\%2Fzkufbd.v9i2.1237

72. Arafeh RM, Shibli RA, Al-Mahmoud M, Shatnawi MA. Callusing, cell suspension culture and secondary metabolites production in Persian Oregano (Origanum vulgare L.) and Arabian Oregano (O. syriacum L.). Jordan J Agric Sci. 2006;2(3):274-81.

73. El-Gengaihi S, Taha HS, Kamel AM. In-vivo and in-vitro comparative studies of Origanum species. J Food Agric Environ. 2006;4 (3\&4):127-34.

74. Hussein Y, Amin G, Hashem E-S, Youssef K. In-vitro Cultivation of Marjoram (Origanum majorana L.) under influence of 2, 4-D (2, 4-Dichlorophenoxy Acetic Acid) as herbicide. Life Sci J. 2014;11(2):249-57.

75. Gamborg OL, Miller RA, Ojima K. Nutrient requirements of suspension cultures of soybean root cells. Exp Cell Res. 1968;50:151- 58. https://doi.org/10.1016/0014-4827(68)90403-5

76. Nitsch JP, Nitsch C. Haploid plants from pollen grains. Science. 1969; 163: 85-87. https://doi.org/10.1126/science.163.3862.85

77. Phillips GC, Collins GB. In-vitro tissue culture of selected legumes and plant regeneration from callus of Red clover. Crop Sci. 1979;19:59-64. https://doi.org/10.2135/cropsci1979. 0011183X001900010014x
78. Linsmaier EM, Skoog F. Organic growth factor requirements of tobacco tissue cultures. Physiol Plant. 1965; 18:100-27. https://doi.org/10.1111/j.1399-3054.1965.tb06874.x

79. Shetty K, Curtis OF, Levin RE, Witkowski R, Ang W. Prevention of vitrification associated with in-vitro shoot culture of Oregano (Origanum vulgare) by Pseudomonas spp. J Plant Physiol. 1995;147(3-4):447-51. https://doi.org/10.1016/S01761617(11)82181-4

80. Shetty K, Curtis O F and Levin RE. Specific interaction of mucoid strains of Pseudomonas spp. with oregano (Origanum vulgare) clones and the relationship to prevention of hyperhydricity in tissue culture. J Plant Physiol. 1996;149(5):605-11. https://doi.org/10.1016/S01761617(96)80341-5

81. Ueno K, Shetty K. Effect of selected polysaccharide-producing soil bacteria on hyperhydricity control in Oregano tissue cultures. Appl Environ Microbiol. 1997; 63(2): 767-70. https://doi.org/10.1128/AEM.63.2.767-770.1997

82. Bafana A. Diversity and metabolic potential of culturable rootassociated bacteria from Origanum vulgare in sub-Himalayan region. World J Microbiol Biotechnol. 2013;29:63-74. https://doi.org/10.1007/s11274-012-1158-3

83. Abdel-Massih RM, Fares R, Bazzi S, El-Chami N, Baydoun E. The apoptotic and anti-proliferative activity of Origanum majorana extracts on human leukemic cell line. Leukemia Research 2010;34:1052-56. https://doi.org/10.1016/j.leukres.2009.09.018

84. Hussain AI, Anwar F, Rasheed S, Nigam PS, Janneh O, Sarker SD. Composition, antioxidant and chemotherapeutic properties of the essential oils from two Origanum species growing in Pakistan. Rev Bras Farmacogn. 2011; 21(6):943-52. https://doi.org/10.1590/S0102-695X2011005000165

85. El Babili F, Bouajila J, Souchard JP, Bertrand C, Bellvert F, Fouraste I, Moulis C, Valentin A. Oregano: Chemical analysis and evaluation of its antimalarial, antioxidant and cytotoxic activities. J Food Sci. 2011;76:512-18. https://doi.org/10.1111/j.1750-3841.2011.02109.x

86. Dhaheri YA, Attoub S, Arafat K, AbuQamar S, Viallet J, Saleh A, Agha HA, Eid A, Iratni R. Anti-metastatic and anti-tumor growth effects of Origanum majorana on highly metastatic human breast cancer cells: Inhibition of $\mathrm{NF} \kappa \mathrm{B}$ signaling and reduction of nitric oxide production. Plos One. 2013;8(7):e68808. https://doi.org/10.1371/journal.pone.0068808

87. Rao S, Timsina B, Nadumane VK. Evaluation of the anticancer potentials of Origanum marjorana on fibrosarcoma (HT-1080) cell line. Asian Pac J Trop Dis. 2014;4(1):S389-S394. https://doi.org/10.1016/S2222-1808(14)60476-X

88. Elshafie HS, Armentano MF, Carmosino M, Bufo SA, De Feo V, Camele I. Cytotoxic activity of Origanum vulgare L. on hepatocellular carcinoma cell line HepG2 and evaluation of its biological activity. Molecules. 2017; 22:1435:1-16. https://doi.org/10.3390/molecules22091435

89. Makrane H, El Messaoudi M, Melhaoui A, El Mzibri M, Benbacer L, Aziz M. Cytotoxicity of the aqueous extract and organic fractions from Origanum majorana on human breast cell line MDA-MB-231 and human colon cell line HT-29. Adv Pharmacol $\quad$ Sci. $2018 ; 3297193: 1-9$. https://doi.org/10.1155/2018/3297193

90. Spyridopoulou K, Fitsiou E, Bouloukosta E, Tiptiri-Kourpeti A Vamvakias M, Oreopoulou A, Papavassilopoulou E, Pappa A, Chlichlia K. Extraction, chemical composition and anticancer potential of Origanum onites L. Essential Oil Molecules. 2019;24:2612:1-15. https://doi.org/10.3390/molecules24142612 